\title{
Mothers 'Doing' Difference: Class, Ethnicity, and Early Care in the Czech Republic ${ }^{1}$
}

\author{
Katarína Slezáková ${ }^{2}$ \\ Institute for Research in Inclusive Education, Masaryk University Brno

\begin{abstract}
Mothers 'Doing' Difference: Class, Ethnicity, and Early Care in the Czech Republic. This text focuses on meanings of class as formulated by mothers in regard to the early care and education facilities that are attended by their children. We ${ }^{3}$ approach class from feminist perspectives that enrich analyses by considering the cultural dimensions. Inspired by the approach of Christina Scharff, we combine ethnomethodology with discursive psychology to analyse ways that actors 'do difference'. The article draws on semi-structured interviews with mothers and explores ways of 'doing difference' in two facilities: an exclusive private kindergarten and a kindergarten in a disadvantaged neighbourhood. This comparison enables us to see how 'middle class' operates as a normative category and how its meanings are modified by race and ethnicity.

Sociológia 2019, Vol. 51 (No. 6: 623-641)

https://doi.org/10.31577/sociologia.2019.51.6.26
\end{abstract}

Key words: Class; ethnicity; early care and education; doing difference; Czech Republic

\section{Introduction}

Class is often thought of as a traditional category in sociology. Theorising about class can be traced back to Marx (1954) and Weber (1978) and continues actively (in the works of Bourdieu 1986; Lamont - Fournier 1992; Walkerdine et al. 2001; Devine 2004; Skeggs 2004; Lawler 2005; Wacquant 2008; Scharff 2008), even among Slovak and Czech social scientists (Nedbálková 2018, 2012; Sopóci 2011; Bunčák et al. 2011; Katrňák 2012; Katrňák - Fučík 2009). Interestingly, while other categories such as gender and race have found consensus at least on their analytical relevance for understanding post-modern society, there are ongoing debates regarding class due to its unclear and constantly changing meaning (Nedbálková 2018). Beck (1992; see also Beck Beck-Gernsheim 2002) viewed society through the prism of individualisation, which he deemed more relevant for understanding conduct than the homogenising force of class. Class then remains a 'zombie category' (Beck - BeckGernsheim 2002), because reflexive practices of the self are broadly available to everyone (Giddens 1991: 3). This perspective has been critiqued as generalising the specific experience of the (white) middle class and therefore

\footnotetext{
1 Acknowledgements: This work was supported by the Czech Science Foundation under grant GA16-18940S.

2 Address: Mgr. Katarína Slezáková, Institute for Research in Inclusive Education, Faculty of Education, Masaryk University Brno, Poříčí 31a, 60300 Brno, Czech Republic. E-mail: slezakova@ped.muni.cz

3 The author uses the first-person plural in this article to emphasise the collaborative nature of the broader research project that includes this text.
} 
rendering the experience of the 'underprivileged' invisible (Skeggs 2004: 5254; Savage 2000: 107-108). The line of authors who conceptualise class in the context of culture, lifestyle, and choice (Bourdieu 1986; Lamont - Fournier 1992) recognise class as a category that inherently represents 'partial perspectives of power and particular interests' (Skeggs 2004: 44) and as a 'mechanism through which situated social action contributes to the reproduction of social structure' (West - Fenstermaker 2002: 541).

This article enters debates about current meanings of class from the perspective of the actors, examining the ways they 'do difference' when talking about early childhood education and care (ECEC). When we talk about 'doing difference' or class, we mean the act of 'creating differences among members of different sex categories, different race categories, and different class categories' (West - Fenstermaker 2002: 541). Based on an empiricallygrounded study, we examine the 'assumptions which take middle-class experience to be normative' and which thus 'discursively construct workingclass parents as ill-informed and less or inappropriately involved in their children's education' (Reay - Ball 1997: 90-91). Furthermore, we show how an intersectional feminist approach to analyses can enrich ethnomethodological discussion about everyday classed practices. The educational system is a central point for studying social mobility (e.g. Van Galen - Dempsey 2009; Bettie 2003; Reay - Ball 1997). ECEC specifically is considered to be vital in helping prepare children for compulsory education, an investment that yields substantial economic benefits (Van Laere et al. 2014), as well as a tool for alleviating social inequality (Entwisle - Alexander 1993; Ramey et al. 2000). Most studies concerning school selection, however, focus on later stages of education. The changing value of higher education leads to the increasing importance of relative advantages even in pre-school education. This, together with discourses establishing the 'educational support and engagement in the system... as a private rather than a public responsibility' (O'Brien 2007: 160), serve as incentives to explore class in relation to ECEC.

In the feminist paradigm of class, there is a shared view of how 'middle class' operates as a normative category. The neoliberal narratives construct the subject as normatively middle classed in opposition to the working-class disgusting 'other' (Lawler 2005: 430). Skeggs (1997a; 2004), Lawler (2005), and Scharff (2008) agree that the perception of 'working class' has 'moved from a focus on a masculinised proletariat (the "noble worker" narrative) to a feminized underclass (the "fag-smoking teenage mother" narrative)' (Lawler 2005: 436). This understanding of 'working class' as feminised encompasses a sense of idleness or unemployment; relatedly, women as such were generally positioned ambivalently in relation to class, causing the misrecognition of their pain and desire (Walkerdine 2003: 238). We are interested in the perspectives 
of mothers, who tend to be more involved with the everyday activities related to school selection (O'Brien 2007) in a context that makes 'the possibility of upward mobility a necessity' (Walkerdine 2003: 239-240). We analyse interviews with mothers regarding the choice of kindergarten and explore the possibilities of combining ethnomethodology with discursive psychology as introduced by Scharff (2008), while reflecting upon the narratives that produce an 'autonomous liberal subject made in the image of the middle class' (Walkerdine 2003: 240).

The normative character of middle classed practices proved a valuable point of entry for our analyses. Since Skeggs maintains that amorality is not only ascribed to those beneath us, but also to those above us (1997b: 132), we selected two kindergartens for this study that stand at the very opposite ends of the spectrum we investigated. We chose the exclusive Falcon private school in a residential area near the city centre and the Mockingbird public school, located in a disadvantaged neighbourhood with a high Roma population. In the course of the analytical process, we found the ways in which mothers 'do difference' to maintain class status and category from such distinguished groups as strikingly similar in some ways. Almost all the mothers talked about the fear of intractable masses (implicitly working class, often non-white) that pose a threat to the advancement of their children or may contaminate them with poor behaviour. This suggests that discursive practices help us understand how culturally and intersectionally conceptualised class in particular and 'othering' in general works for different types of actors. This then allows us to see how the 'doing' of the actors reifies social structures in practice.

We first present the broader background of this study and set out our basic theoretical assumptions about how people 'do difference'. The main part of this article consists of a close examining of mother utterances, along the analytical lines suggested by Scharff (2008). Special attention is paid to the intra-actions of class and ethnicity. First, we explore the changing meanings of private schooling in the context of a post-socialist country, where it usually is connotated negatively. We then discuss the ways in which the mothers presented the threats to the academic development of their children and how classed perspective can help understand these presentations. Third, we address the connotations of ethnicity and the meaning of racializing processes in the context of classed practices. We conclude with a discussion of how these contexts form the strategies that mothers choose to present as respectable.

\section{Background}

This study forms a part of a qualitative research project focusing on ECEC in the Czech Republic. We use data from semi-structured interviews with parents and kindergarten directors that we conducted in 2016 and 2017 in a large city. 
The interviews dealt with the topics of kindergarten choice and the parents' experiences with the current early care system in the Czech Republic. After the interviews, we also collected questionnaires that provided information about household status, income, education, and employment.

We chose six facilities offering childcare services for children ages 3 to 6 . We selected three public facilities, with high, medium, and low parental demand (based on the number of applications per place offered) and three private facilities offering their services at high, medium, and low prices (in the context of the city of research). These different types of facilities are not meant to be representative of the diversity of services in the city of our research or in the Czech Republic, but rather to delimit the range of currently available services. We based our selection on available criteria that allowed us to organise the local facilities into groups from which we picked potential facilities to contact. In the facilities that agreed to co-operate, we conducted an interview with the directors and then started contacting parents for interviews. In most cases, the directors were open to the research and the interview; the reactions of parents varied substantially based on the type of facility. We only discuss the perspectives of mothers in this paper, since those are the only parents we could reach in case of Falcon and Mockingbird (and most other kindergartens). Even if we also invited fathers to participate in the research, we ended up interviewing only two of them altogether. In most families, we were referred to the mother, as she was said to be the one more informed about the issues related to kindergarten. As a result, the interview data we gathered for our six types of facilities do not necessarily provide the full picture of families in the given kindergarten. The collected interviews, however, make it possible to explore the ways the interviewed mothers 'do difference'.

For this article, we decided to compare two facilities: the exclusive private English-language kindergarten Falcon (located in the city centre) and the public kindergarten Mockingbird (located in a disadvantaged neighbourhood with a significant Roma population). This analysis is directly based on nine interviews with mothers and on related field notes. Indirectly, we of course understand the data in the context of the interviews and observations from other facilities and in the context of the focus groups from the early stages of the project.

We distinguished two basic types of class status, each of which is strongly connected to one or the other kindergarten. Not surprisingly, above-average incomes and professional occupations that allocate parents into upper-middle class status prevail in Falcon. The very opposite type was found in Mockingbird. Parents mostly had very low incomes and two of three mothers 
were racialized $^{4}$ as Roma by the director. From the perspective of class analysis, the kinds of education children from different class backgrounds get and what the different backgrounds allow their parents to do are revealing. We look at the ways that participants talk about private and public education and how they 'do difference' when talking about it.

\section{'Doing difference': intra-actions of class and ethnicity}

In Crompton's (2008) categorisation, class can be understood on three levels: a) class as status, culture, or prestige, b) class as structured inequality, and c) class as political identity. In this paper, we explore the cultural aspects of class as actors subjectively make sense of those aspects; this has further implications on the available identity formations and on the potential of classes as political actors as well as on the legitimisation of structured inequality. However, we see their interaction as mutual and plastic, rather than as a consequential causality.

When thinking about how class is 'done' in situated contexts, we follow West and Zimmerman (1987) and West and Fenstermaker (1995; 2002). Based on their work on 'doing gender' and 'doing difference', we established three categories to analytically dissect class: class status, class category, and 'doing' class. Class status is the combination of income, education, and profession that puts actors into specific positions in terms of the social power structures. Class category is the category to which actors are held accountable, meaning the 'ever-present possibility of having one's actions, circumstances, and even, one's descriptions characterised in relation to one's presumed membership in a particular category' (West - Fenstermaker 2002: 541).

We combine ethnomethodology with discursive psychology, as suggested by Scharff (2008), because it 'contributes to a cultural approach to class by illuminating the various ways in which it operates at the level of talk and interaction' (p. 349). The focus is on the discursive practices of (dis)identification, establishing respectability and responsibility (or their absence), and the construction of a reflexive self (or its absence) as central ways of discursively performing and reproducing class. However, the actors themselves rarely speak about class directly, especially those who 'do not want to be reminded of their social positioning in relation to [class]' (Skeggs 1997a: 77). Often, they speak about class in terms of other concepts, for example 'the self... brought to existence thorough particular discourses' (Skeggs 2004: 5-6) or by constructing symbolic boundaries in society (Lamont - Fournier 1992).

\footnotetext{
4 In this study we use the terms ethnicity and race, or ethnicization (Sidiropulu Janků 2004) and racialization interchangeably. Roma, the discussed racialized group here, are mostly considered as an ethnicity. However, we regard both categories and processes as socially constructed; in this case, they have identical outcomes for the actors.
} 
An intersectional lens can uncover the complexities in which the axes of difference (here mainly class and race/ethnicity) interplay or, better said, intraact (Lykke 2010: 49) to gain a deeper understanding of how these categories shape actors' sense-making. Intra-action refers to ways in which these entities 'interpenetrate and mutually transform each other' (Lykke 2010: 49). This makes it possible to discover the various modes of overlap between class and ethnicity and race and make the intra-actions explicit, as they sometimes go unexpressed by participants (Bowleg 2008). Our writing is mostly based on class theories and explores how class intra-acts with ethnicity and race, as opposed to the approach taken by Lykke (2010), who focuses on gender and puts it an intersectional perspective. Therefore, when interpreting the data, we enter the analysis through class, but are interested in how other categories intraact with class.

\section{No more free pass: changing meanings of private schooling in the Czech Republic}

In the context of the post-socialist Czech Republic, parents sending their children to private kindergartens have to redefine the meanings connected to public and private education in order to legitimise their choice of an exclusive kindergarten. Mothers from Mockingbird racialized as Roma never mentioned the existence of private kindergartens in the interviews. Living in the neighbourhood where significant number of families cannot afford quite low fees in public ECEC facilities (approx. 20 euros per child), it is unimaginable to even consider private options (where the fees vary between 200 and 500 euros). The world of private schools is not accessible to these mothers and therefore they are not concerned with it - parental decisions about child-care are subjected to actual policies and institutional setting that sets limits to their choice (Lutherová et al. 2017: 293). The third mother from Mockingbird, Alena, who was racialized as white (and self-identified as 'middle or intellectual class'), mentioned private schools only marginally and disregarded them as an option for her family. She saw them as a 'matter of social status' with 'very alternative programs' or 'ambitious projects to collect as many language certificates as possible'. Since public schools are considered to be of higher quality, true meritocratic institutions, Falcon mothers had to deal with sceptical beliefs about private education. Zuzana, who herself studied at a private school, felt that her education was undervalued compared to a public school education:

"At that time, private education was considered inferior, of lesser quality, because people paid for it, so supposedly they got diplomas without having to do anything. It wasn't true, but it was perceived this way by others."

(Zuzana, Falcon) 
Here the mother acknowledges that there is a general negative perception of the private school system, but she works around the perception. First, she denies that her school was any easier and asserts that she did have to work for her degree. Second, she places this narrative into the past:

"Today it's different, today a private school doesn't mean that you can pay to get the diploma, or that you don't have to do anything. It is more and more the other way around, it is about quality... Because of the budget they have, they can afford better equipment, better environment; I think it is about quality." (Zuzana, Falcon)

Zuzana here creatively works with disclaimers (Scharff 2008) that enable her to take her own stand and present her own perspective in relation to the class category to which she is held accountable (West - Fenstermaker 1995). In other words, she is able to construct a reflexive self. This ability has been deemed as not being distributed equally among the classes (Skeggs 2004) but being prevalent with (upper-)middle classes. Therefore, it can be understood as a signifier of power (Scharff 2008). Using disclaimers makes Zuzana able to confirm that while many private schools in fact granted diplomas without requiring too much work, a) that was not the case for her school and b) this is no longer common. She shows that she is aware of perceptions connected to the private school system, but she has her own experiences, past and present, that disprove them. On the contrary, she asserts that private education is improving precisely because it is private; that is, there is enough money to provide a good learning environment, tools, and methods. She creates a dichotomy in which private schools are associated with an abundance of resources and knowledge, while public schools are seen as sites of 'lack' (Lawler 2005).

Similarly, Ivana understands public kindergartens as 'a place where a child is left' while parents need to be at work. There are some advantages for the child, such as meeting other children and learning how to get along with them. However, the added value of the professional and expert care of a private kindergarten is missing; this is amplified by the high number of children per teacher in public schools. This mirrors the overall picture of the public school system that is portrayed by Falcon parents. When Lucie was asked about her opinion of the coexistence of private school and public school systems, she replied:

"Well, I think it is fine that a person can choose. If I found myself at the point where I was a single mother with a little child, working part-time somewhere, then I believe I would be extremely thankful that it (the public school system) is here. On the other hand, I think that there shouldn't be such differences, but that is systemic, it is the problem of the system here." (Lucie, Falcon) 
The classed distinction here copies the lines of private-public education, emphasised by the reference to single mothers, one of the most common representations of the feminised working class. However, in this case the mother does not refer to them disrespectfully: she acknowledges that if she found herself in that situation, she would be glad to have an affordable public kindergarten. This demonstration of solidarity goes against much of what is described by other similar parents and in the literature (Scharff 2008; Skeggs 2004). Apparently, there are points at which upper-middle-classed parents did not feel the need to overemphasise their distance from working-classed parents. Doing class is always a situated action, and it can include 'reinstating or critiquing existing systems of classification' (Scharff 2008: 385). It is interesting that this is the only case of critiquing systems of classification that was found in our data, especially because it came from a mother with uppermiddle-class status. Nevertheless, there is still a clear distinction between private and public kindergartens. While the public school is seen as a good affordable child-minding service for single mothers and other poorer parents, the private kindergarten is associated with an abundance of resources, added value, and an individual approach to children and also to parents.

\section{Setting the golden mean: on being 'just right'}

The ways in which private and public schools were inscribed with meanings were the bases of how difference was done by the Falcon mothers. They were concerned about the number of pupils per teacher in public schools. Parents, implicitly and often very explicitly, expressed worry about working-class (nonwhite) masses that the state cannot control due to a lack of resources. Monika, a Falcon mother, stated that she is worried for her son in public school since there are 'thirty children per teacher'. She deemed it impossible for her 'introverted' son to do well in a public school, because 'he would be put right away into some box as a naughty boy', which would hurt him and, in turn, make him naughty. Indirectly, she said she did not trust teachers to do their job properly. Introversion is portrayed as incompatible with the masses of pupils in public schools. This attitude can be identified among white (upper)middle-class parents of boys who fear the undesired types of hegemonic masculinity, implicitly working-class and non-white, that can threaten academic success (Williams 2008).

Narratives of fragility related to masculinity appeared also in Mockingbird, and they served similar ends. Anna, a mother racialized as Roma, established a similar self-presentation through talking about the experiences with bullying that her older son, who has dyslexia, endured. She worried about maintaining a 'good collective' in Mockingbird free of 'the other', the bad kids, the bullies and their families, who are coming due to the changing composition of her 
neighbourhood. She relates the shifting structure to a worsening situation in the area where they live, due to gentrification in an adjacent neighbourhood. Since apartment buildings in some 'worse' parts of that adjacent quarter are being sold, the tenants are moving into the district designated for Mockingbird students. Anna identified the threat to the academic success of her son as being outside of the kindergarten - while the teachers and the facility itself provided a safe haven for him. This allocation of danger outside of the kindergarten is emphasised in terms of the building itself: it is surrounded by a high fence that (also symbolically) protects it from the outside world. For Anna, being 'just right' means pulling herself up through the public kindergarten and affiliating herself with the teachers, who are the bearers of sophistication and morality.

For the Falcon mothers, the threat lies within the public school. They talked about the masses and also talked about the incapability of the teachers, who are underpaid and understaffed, which causes them to be unenthusiastic at work. The mothers asserted that only facilities with substantial budgets, or the ones that are so small they allow for individual approaches, can provide a healthy environment for creating good practices. Lawler (2005) notes that the working class 'landscape and inhabitants are so frequently described in terms of lack' (ibid.: 433). This is not necessarily connected to material resources but to 'right ways of being and doing' (Bourdieu 1986: 511). In this case, these seem to go hand in hand. Private schools have resources to secure a sufficient and wellprepared staff. This means that there are exponentially fewer pupils per teacher; furthermore, these teachers are better equipped to pay individual attention to each child. Meanwhile, public schools are associated with the masses and with incompetent teachers. This is in line with Skeggs, who finds that 'working classes have a long history of being represented by excess, whilst the middleclass are represented by their distance from it, usually through associations with restraint, reasonableness, modesty and denial' (1997a: 99). The working classes are associated with being too much: too loud, too wild, and too uncontrollable. Simultaneously, the working class is perceived as not enough: they don't have the right ways of doing, they lack sufficient resources, manners, or knowledge, and they just aren't progressive enough. 'They' here serves to create a 'fictive ' $w e$ '... that symbolically excludes anyone not middle-class' (Lawler 2005: 432). When Skeggs talks about excess and Lawler about lack, even though it may seem contradictory, they mean the same thing, or at least two sides of the same story - the narrative of the disgusting working classes. The mothers were very careful to distance themselves from this depiction in order to establish themselves as middle class.

The Falcon mother Monika mentioned considering the public kindergarten in the small town where they live. Outside of the city, located in the suburbs, the small-sized facility promised to overcome the shortcomings of other public 
schools; however, there were no vacant spots. Therefore, she started looking elsewhere, and the expensive private facility became an option. She openly expressed concern that Falcon would be a bad influence on her child due to its exclusive nature. She expected the other parents to be well off, thus snobbish and detached from reality. This initial expectation reflects a class category to which the Falcon parents are held accountable: upper-middle-classed, associated with being pretentious (Lawler 2005). Monika realised that by being a part of this specific kindergarten, she and her family were also held accountable to the upper-middle class category. Her statement that she was unsure about the choice serves to disidentify with this class category, or at least with some of the negatives associated with it.

This awareness of accountability appeared repeatedly in other interviews, mostly through something that we call 'the fear of the lazy child'. Lucie (Falcon) summarised it thus: 'I don't want to have a child who is always tired and will be just running around and live, like, this easy lifestyle'. She wants her children to get used to hard work and she made it clear that this is one of her most important values by emphasising that she and her husband work around the clock and they are certain this quality is something they want to pass onto their daughter. It is essential for her that her daughter be 'used to productive activity [and] to know that nothing in life is for free'. Lucie feels that she and her husband are building something together and they would like their daughter to take up this effort. Here, she reflects and works around the stereotype of a spoilt rich child who is granted everything and does not have to try very hard to achieve anything and thus becomes frivolous and reckless. She thinks of idleness with great disdain - this is probably due to her own experience. She mentioned in other parts of the interview that she herself grew up in 'housing estates'. Now with a substantial income and university education, she credits her success to her own hard work and diligence. Emphasising this enables her to present herself as respectable in a middle-classed way: as having only what she has accomplished through hard work, no more, no less. In this way, she is disidentifying and distancing herself from the feminised working class, but also reflecting the class category to which she is held accountable. It would seem that there is one respectable way to be, and that is to neither lack anything nor have anything in excess or abundance. It is the adequacy of middle class.

\section{Same same, but different: the racialized other}

Mothers repeatedly showed concern about the masses of pupils but also the dissimilarity of the other families in terms of class and ethnicity. One of the Falcon mothers, Lucie, talks about the choice of private kindergarten while referring to 'certain groups of citizens' that the public school system fails to control, which in turn threaten the rights of other people. 
"Nevertheless, there are certain groups of citizens that attend, like, public schools, and they have the right to an education, I am not taking that away from them, but they have to respect the rights of other people and I think there are no measures here for that. For example, where we live, we kinda live on the border of two areas. And the kindergarten we would fall into, there are the housing estates and a lot of junkie families, there were also many incidents with these like junkie families, to put it bluntly." (Lucie, Falcon)

By 'other people', she means anyone who is not from those 'certain groups of citizens'. Class-wise, she uses the coding of 'housing estates' and 'junkie families' to dis-identify (Scharff 2008) herself from the working class, even though she herself grew up in the 'estates'. This experience is given as a reason she wants her daughter to stay as far away from 'those people' as possible. Besides creating distance from the working class, which is essential for fostering the image of middle-classed moral purity (Lawler 2005), Lucie also indirectly talks about the Roma; this can be understood from several references to locality, by her mentioning the coded 'inability to respect rules', and from the provided disclaimer detailed below. This shows how the undesirable affiliation with the working class is also a racialized assumption about the 'masses'.

When talking about 'certain groups of citizens' who do not respect the rights of others, Lucie opens by saying:

"And I don't even want to talk about these, and I need to say, me and my husband, we are not racist, we have no problem with other nationalities, cultures, we both have lived abroad, we have no problem with that." (Lucie, Falcon)

First, Lucie employs a textbook-like disclaimer (Scharff 2008: 397) 'I am not racist' and supports this claim through an account of international experiences. Then she continues by giving reasons why she prefers private education and why she does not want her daughter to attend school with kids from the 'estates' and from 'junkie families'. To conclude, she says 'I don't want it to sound snobbish or pretentious'. She is able to work around the topic of racist and classist exclusion and present herself as open and liberal, while at the same time establishing the exclusivity of private schools as a means of creating a healthy environment for her children. She maintains the allure of cosmopolitanism associated with the middle classes and she can reproduce structural inequality narratives while still maintaining this desired selfpresentation as moderate and progressive (Scharff 2008). This situation shows the thin lines between class and ethnicity and race in everyday practices and how they can intra-act in people's utterances to make the distance between the 
orator and the undesirable group even wider. In this way, the act of class distinction can also be a process of racialization.

This ethnicizing talk has an interesting twist when it comes to ethnic diversity at Falcon kindergarten. Here, ethnicity is not understood as a source of danger, but rather as a positive benefit of the kindergarten that enables children to experience diversity and to become accustomed to different languages, cultures, and traditions. This is closely related to how class and ethnicity operate together. Roma are associated with the feminised working class represented by 'junkies', single mothers, and 'estates'; at Falcon, ethnicity is formulated mostly in terms of 'expats'. They are seen as worldly, cosmopolitan professionals; affiliating with them transmits these desired characteristics onto oneself. Therefore, the racialized people mentioned who are not seen as Roma, refugees, or immigrant workers are viewed in a positive light. They show children a variety of languages and cultures and make them more aware of differences across the world: their class status and category balance out their otherwise racialized identity.

Both abovementioned processes related to ethnicity/race and class merge in Alena from Mockingbird. Her situation is specific, she is middle-classed in status and in self-identification, racialized as white - yet her son attends kindergarten that is in disadvantaged neighbourhood (different from the neighbourhood the family lives in). This came about by necessity: Alena wanted to go back to work shortly before her younger son turned three. Although her older son already attended her kindergarten of preference (which makes it much easier to get a place), the then two-year-old was not accepted. The only free spot opened up in Mockingbird. Originally, she was worried about the presence of the Roma children, but now, she is happy with the 'multicultural environment' and that her son 'has no issue calling Vietnamese or Roma children best friends'. When asked about the social composition of Mockingbird she says:

"Our kindergarten is diverse and colourful. Like, the expected happens, there are T-shirts and other stuff going missing from the lockers, although not lately, as far as I know. Yet again, teachers there, they know how to work with this situation. Like now, there is a notice hanging on the door how to get meal benefits at the kindergarten. So, the people there, they know how to manage it so it doesn't reflect negatively in any way. Like there are children who are "social cases", Roma children, Vietnamese children, white children, all kinds of children, but it doesn't have any negative effects whatsoever." (Alena, Mockingbird)

On the one hand, Alena sees the diversity of the kindergarten through the lens of multiculturalism as a positive value: her son is able to communicate with and befriend children of other ethnicities/races or class categories. This is 
comparable to Falcon mothers talking about the 'expat children'. On the other hand, she also associates the non-white working-classes with improper behaviour (stuff going missing) or with lack (the need for benefits). She herself views these children (and their parents) as something to be controlled and managed in order not to have negative impact on majority population represented by her son. This also strikingly resembles the narratives of Falcon mothers who are scared of public schools' inability to manage the 'masses'. Nevertheless, Alena was put into a situation where she had to risk potential negative outcomes and ended up convinced by the experience in Mockingbird. She feels that the expertise of the kindergarten personnel is able to mitigate or even eliminate the negative impacts of having diverse group of children on the majority. This moulds the meaning she ascribes to ethnicity/race. Here, nonwhiteness is not balanced out by the class status of the children themselves, but by the class status of the teachers and the headmistress, who ensure these families are kept in check.

\section{Don't touch anything: contagion of irresectability}

Mothers are unsurprisingly concerned with the health of their children. However, on some occasions we recognised that the talk of germs and becoming sick also serves other goals regarding class.

"To compare it with the public kindergarten she used to attend, then yes, the activities are a plus, but the negative is that they get there by public transport, so I can't really say that the activities are super extra plus on the kindergarten, because honestly I would be much happier if my daughter was healthy and didn't attend these activities." (Tereza, Falcon)

Here, Tereza is very worried about her daughter becoming sick from using public transport, to the point that she would rather forego the extra activities if this would mean avoiding public transport. Infectiousness is used to legitimise social exclusionism. It is implied that being 'out there' (in public school or on public transport) greatly increases the probability of becoming infected and that this risk can be avoided by having the children in private institutions. The contact with the public that occurs when traveling to tennis and swimming classes is disdained, suggesting that class unification is one reason that mothers choose private institutions. Often, they use metaphors of the masses, housing estates, and contagious infections to legitimise their preference for private schooling. This also serves in distancing themselves from working-classness, 'which must then be guarded against, since to do otherwise would be to threaten the stability of middle-class claims on respectability' (Skeggs 2004).

The mothers from the Mockingbird kindergarten practiced disidentification with 'the other' in a similar manner. At the end of her interview, Nikol (Mockingbird) worried about the influx of new families to her neighbourhood. 
She stated that she had to change paediatricians for fear that her children might catch something. When she says, 'I go to see the doctor with my son, who has a fever and a cough, and return home with typhoid' she employs the same differentiating mechanisms as mothers from Falcon. Furthermore, she emphasises the distance between herself and the others by saying that the last time they went to see the doctor, she forbade her son to touch anything. Even things that were used by the 'bad people' are out of bounds for her, because as a woman of colour living in a disadvantaged neighbourhood, she is aware that she is categorised in a way that codes her as incapable, failing, and amoral.

To navigate this narrow space, limited by class categorisations and further reduced by being racialized, mothers from Mockingbird become passionate when talking about the recent change in the law requiring all children to attend a compulsory year of pre-school starting in September 2018. This means the influx of children from 'bad' families, i.e. families who do not pay the rent and have lots of debt yet receive social benefits, into Mockingbird and hence the creation of a 'bad collective'. Nikol expressed fear that the new children would have a negative influence on her son. Here she creates two groups: a 'we' group that pays rent and overall is portrayed as respectable citizens and the 'others' that are signified by their irresponsibility. This practice serves to disidentify with working-classness, as demonstrated in previous cases. Here we can also observe the actor establishing herself as responsible. Skeggs understands 'responsibility as one of the key signifiers of respectability' (1997a: 56) and '[r]espectability is one of the most ubiquitous signifiers of class' (ibid.: 1). This aspect is emphasised further when Nikol mentions that she does not receive any benefits. Here she navigates the classed territory, both distancing herself from the category that she does not want to be associated with and actively working with racialized stereotypes of Roma living off welfare, not wanting to work, being lazy and shifty. We can observe here how class and ethnicity intra-act. Nikol finds herself in a tricky situation: she wants to avoid being seen as poor, when poverty is understood as a result of individual incapability and failure. She also needs to acknowledge that she is racialized, which gives her an even narrower scale of what she is allowed to be without whiteness to support her stance. Yet she manages to present herself as responsible in the interview, hence establishing a respectable position for herself.

On the other side of the coin, in Falcon, is the appreciation that the other parents are alike: they are from a similar social background, which ensures that they want the same things and have money to pay for them (e.g. for professionally led tennis and gymnastics classes). In a public kindergarten, the other parents might be problematic because they are associated with irresponsibility. This becomes obvious when Lucie compares the current 
Falcon kindergarten to her previous experience, also with another private institution:

"That director, she tried really hard, she worked, and that kindergarten accepted children from, like, various social backgrounds and there was a problem that there were always sick kids at school.

Our daughter was unbelievably sick, always at home, and my husband, every time he went to drop her off, came back annoyed. He used to say: 'I diagnosed it all there, when we were taking off her jacket,' he says, 'half of these kids are contagious and should be at home,' and he was always angry." (Lucie, Falcon)

Here two private kindergartens are compared; however, Lucie perceives a qualitative difference in the composition of families surrounding them. While the old kindergarten was more diverse in terms of class categories, she recognises Falcon as being more unified. This means that the parents are perceived as alike and therefore respectable. This is established by parents behaving responsibly and not letting children go to school when they are sick and infectious. In the diverse kindergarten, parents sometimes had no choice and 'just tossed them there'. With this disparaging language, the mother emphasises the recklessness with which parents from the less prestigious private kindergarten acted compared to the parents at Falcon. Moreover, she refers to her husband, a doctor, asserting support through his expertise. Here we see how various rhetorical devices go hand in hand: disidentification and establishing respectability are not mutually exclusive. Generally, actors creatively employ several tools at once to strengthen their narratives.

\section{Conclusion}

This empirically-grounded study explored the various ways in which mothers 'do difference' in terms of the early care and education facilities with which they are associated. Furthermore, we examined the ways in which class and ethnicity intra-act in the way the mothers talk about private and public school systems and where they identify threats to the future academic success of their children. We demonstrated how the meanings attached to private and public education are changing (in the context of the Czech Republic) regarding current narratives of working-classness. Furthermore, we explored their worries about potential disruptions to the academic development of their children from the masses; however, the mothers assigned the worries to different sources. For (upper)middle-class mothers, the public school system was threatening due to overcrowded classrooms or the 'lack' of resources and the right ways of doing (Lawler 2005); for Mockingbird mothers, the focus was on what lies outside of the kindergarten. Working-class mothers of colour feared that the influx of 'bad 
children', meaning those that are not yet part of the system, or those who come from so-called 'asocial' 5 families, would contaminate the kindergarten environment with bullying or even diseases. This different understanding of 'the masses' shows how the same mechanisms of class create different conduct for actors in distinguished and hierarchically organised positions. All the mothers were aware of the categories to which they are held accountable, but they had to employ different strategies, depending on their class status and racializing processes, to present as respectable. For Mockingbird mothers, kindergarten, as an educational institution, was an embodiment of middleclassed adequacy, giving them the opportunity to earn respectability through affiliating with it. They recognised the negative connotations with which their mere existence is burdened, as non-white non-middle class in status, and they navigated these connotations. This shows their agency and problematizes popular narratives of working-class passivity. For Falcon mothers, it was practices of the self (Skeggs 2004), such as disclaimers (Scharff 2008), that enabled them to present as progressive, thus respectable.

The differing access to power is apparent in the lack of criticism coming from Mockingbird mothers. Scharff (2008) and Skeggs (2004: 114) claim that 'accusations of middle-class pretentiousness represent one significant challenge to degrading systems of classification', meaning that problematizing the order of things itself might often be one of the few strategies available to workingclass actors to overcome the shame connected to their status. However, among the mothers in this study, it was the upper-middle-classed participants who expressed that the differences between private and public schools are too steep. Mockingbird mothers were very fond of their kindergarten, and their critiques were always reproductions of anti-gypsy narratives, blaming the other Roma for irresponsibility and exploitation of welfare. This might be, paradoxically, explained exactly by the fact that the working-class mothers from Mockingbird are also racialized as Roma, which puts them in an even more vulnerable position towards the kindergarten in general and the researcher doing the interview in particular. To be the obedient and 'good' Roma, one must accept the narratives of the white majority about their own identity, must not complain about racist structures, and must emulate the neoliberal narratives of individually attained success regardless of origin. However, Mockingbird mothers showed an ability to navigate this narrow field bounded by race and class in order to secure respectable positions.

This opens another point for discussion. Scharff (2008), again in alignment with Skeggs (2004), contradicts Beck (e.g. 1992, or Beck - Beck-Gernsheim 2002) and Giddens (e.g. 1991) and the thesis that capacities towards both

\footnotetext{
5 This word is used in the Czech Republic to indirectly, but very specifically, code Roma as unemployed, idle, lazy, and unwilling to follow rules.
} 
structural and self-reflexivity have intensified. Scharff (2008) claims that, as her 'empirically grounded analysis of class and talk however demonstrated, reflexivity is not equally distributed in regard to class; indeed, the use of disclaimers in the production of a moderate and reflexive self is indicative and reproductive of a position of power' (ibid.: 349). While we agree that many practices of the reflexive self are not accessible to the working class, and that hence class is an area of power relations, we also argue for greater sensitivity in recognising working class agency. All actors relate to the class category to which they are held accountable in one way or other. Working class actors in status are equally able to recognise their position. Moreover, they are able to work creatively to either debunk the class structures (as shown by Scharff) or present themselves as respectable, either of which allows them to be successful in contact with institutions such as the kindergarten. We recognise the power structures that are created through actors 'doing class' or 'difference', but we also call for caution so as not to reproduce narratives of passive working classes.

Katarína Slezáková is employed at the Institute for Research in Inclusive Education, Masaryk University as a junior researcher. Her interests include class, gender, race and ethnicity, intersectional feminist theory, ethnomethodology, and qualitative methodology in general. Topics she has covered mostly relate to education, from early care and education to university graduates and academic spaces.

\section{REFERENCES}

BECK, U., 1992: Risk Society: Towards a New Modernity. London: SAGE.

BECK, U. - BECK-GERNSHEIM, E., 2002: Individualization: Institutionalized Individualism and Its Social and Political Consequences. London: SAGE.

BETTIE, J., 2003: Women Without Class: Girls, Race, and Identity. Berkeley: University of California Press.

BOURDIEU, P., 1986: Distinction. London: Routledge.

BOWLEG, L., 2008: When Black+ Lesbian+ Woman $\neq$ Black Lesbian Woman: The Methodological Challenges of Qualitative and Quantitative Intersectionality Research. Sex Roles 59 (5-6), 312-325.

BUNČÁK, J. - DŽAMBAZOVIČ, R. - HRABOVSKÁ, A. - SOPÓCI, J., 2011: K niektorým otázkam sociálnej stratifikácie slovenskej spoločnosti. Sociológia 44(5), 495-527.

CROMPTON, R., 2008: Class and Stratification. Cambridge (UK): Polity.

DEVINE, F., 2004: Class Practices: How Parents Help Their Children Get Good Jobs. Cambridge (UK): Cambridge University Press.

ENTWISLE, D. R. - ALEXANDER, L. K., 1993: Entry into School: The Beginning School Transition and Educational Stratification in the United States. Annual Review of Sociology 19, 401-423. 
GIDDENS, A., 1991: Modernity and Self-Identity: Self and Society in the Late Modern Age. Cambridge (UK): Polity Press.

KATRŇÁK, T., 2012: Is Current Czech Society a Social Class-Based Society? The Validity of EGP and ESeC Class Schemes. Sociológia 44(6), 678-703.

KATRŇÁK, T. - FUČÍK, P., 2009: Preference výběru partnera. Liší se rozvedení a svobodní ve sňatkových a partnerských preferencích? Sociológia 41(5), 437-455.

LAMONT, M. - FOURNIER, M. (eds.), 1992: Cultivating Differences: Symbolic Boundaries and the Making of Inequality. Chicago: University of Chicago Press.

LAWLER, S., 2005: Disgusted Subjects: The Making of Middle class Identities. Sociological Review 53(3), 429-446.

LUTHEROVÁ GYÁRFÁŠOVÁ, S. - MAŘÍKOVÁ, H. - VÁLKOVÁ, J., 2017: Childcare Preferences of Parents in the Czech Republic and the Slovak Republic. Sociológia 49(3), 285-308.

LYKKE, N., 2010: Feminist Studies: A Guide to Intersectional Theory, Methodology and Writing. London: Routledge.

MARX, K., 1954: Kapitál: kritika politické ekonomie (The Capital: Critique of Political Economy). Praha: Státní nakladatelství politické literatury.

NEDBÁLKOVÁ, K., 2018: Sociologie třídy a dělnictví. Sociológia 50(1), 57-77.

NEDBÁLKOVÁ, K., 2012: Tak daleko, tak blízko: dělnická tř́ída v České republice Sociální studia 9(3), 85-100.

O'BRIEN, M., 2007: Mothers' Emotional Care Work in Education and its Moral Imperative. Gender and Education 19(2), 157-177.

REAY, D. - BALL, S. J., 1997: Spoilt for Choice: The Working Classes and Educational Markets. Oxford Review of Education 23(1), 89-101.

RAMEY, C. T. - CAMPBELL, F. A. - BURCHINAL, M. - SKINNER, M. L. GARDNER, D. M. - RAMEY, S. L., 2000: Persistent Effects of Early Childhood Education on High-Risk Children and Their Mothers. Applied Developmental Science 4(1), 2-14.

SCHARFF, C. M., 2008: Doing Class: A Discursive and Ethnomethodological Approach. Critical Discourse Studies 5(4), 331-343.

SIDIROPULU JANKU゚, K., 2014: O leperiben. Partnerství, etnizace a orientalismus v aplikovaném výzkumu (About Leperiben. Partnership, Ethnicization and Orientalism in Applied Research). Biograf (59), 5-32.

SKEGGS, B., 1997a: Formations of Class and Gender: Becoming Respectable. London: Sage.

SKEGGS, B., 1997b: Classifying Practices: Representations, Capitals and Recognitions. In: Mahony, P. - Zmroczek. C. (eds.): Class Matters: Working Class' Women's Perspectives on Social Class. London: Taylor \& Francis.

SKEGGS, B., 2004: Class, Self, Culture. London: Routledge. Pp. 123-140.

SOPÓCI, J. a kol., 2011: Sociálne nerovnosti na Slovensku. Bratislava: STIMUL.

VAN LAERE, K. - VANDENBROECK, M. - ROETS, G. - PEETERS, J., 2014: Challenging the Feminisation of the Workforce: Rethinking the Mind-Body Dualism in Early Childhood Education and Care. Gender and Education 26(3), 232245. 
VAN GALEN, J. A. - DEMPSEY, V. O. (eds.), 2009: Trajectories: The Social and Educational Mobility of Education Scholars from Poor and Working Class Backgrounds. Rotterdam: Sense Publishers.

WACQUANT, L., 2008: Relocating Gentrification: The Working Class, Science and the State in Recent Urban Research. International Journal of Urban and Regional Research 32(1), 198-205.

WALKERDINE, V., 2003: Reclassifying Upward Mobility: Femininity and the Neoliberal subject. Gender and Education 15(3), 237-248.

WALKERDINE, V. - LUCEY, H. - JUNE, M., 2001: Growing-Up Girl: Psychosocial Explorations of Gender and Class. Basingstoke: Palgrave.

WEST, C. - ZIMMERMAN, D. H., 1987: Doing Gender. Gender and Society 1(2), 125-151.

WEST, C. - FENSTERMAKER, S., 1995: Doing Difference. Gender \& Society 9(1), 8-37.

WEST, C. - FENSTERMAKER, S., 2002: Accountability in Action: The Accomplishment of Gender, Race and Class in a Meeting of the University of California Board of Regents. Discourse \& Society 13(4), 537-563.

WEBER, M., 1978: Economy and Society: An Outline of Interpretive Sociology. Berkeley: University of California Press. 